\title{
The Use of Disability Interactive Media to Improve Beginning Reading for Children with Multiple Disabilities Class III SDLB
}

\author{
Reza Febri Abadi ${ }^{1 \star}$ \\ ${ }^{1}$ Sultan Ageng Tirtayasa University, Indonesia
}

\begin{abstract}
This research is based on the problem of lack of the ability to read the beginning, the ability to recognize all the letters of the alphabet has not been felt. It has not been able to incorporate letters into syllables and words in children with multiple impairments. The research aims to improve the ability to read at the beginning of children with various impairments with target behavior, namely reading syllables and word reading ability. The subject of this study was a child with multiple impairments of class III SDLB. The method used is Single Subject Research with A-BA research design. The processed data is presented in a simple descriptive statistical form through graphs and percentage values. The results showed an increase in the reading ability of research subjects using Disability Interactive Media, with evidence that the rise in the mean level of behavior in the ability to read syllables in the baseline-1 phase (A1) got an average value of $50 \%$, the intervention stage (B) got the average value is $86.8 \%$. The baseline stage-2 (A2) earns an average discount of $78.5 \%$. Then a comparison of the mean level of the second target behavior, i.e., the ability to read word between baseline-1 (A1) Gets an average value of 33\%, the intervention phase (B) Gets an average value of $81.37 \%$, and the baseline-2 step (A2) Get an average value of $75 \%$.
\end{abstract}

Keywords: Children with Multiple Impairments, Disability Interactive Media, Beginning Reading Ability

\section{Research Background}

Every child in Indonesia has the right to get an optimal education and educational service facility to develop potential and make it as a child ready to be independent. There is no such thing as discrimination in education, and everyone deserves a proper education. Education is not reserved for children in general, but educational services are entitled to be provided to children with special needs because they desperately need unique or special educational services. This is stated in Law of the Republic of Indonesia No. 20 of 2003 on the National Education System, which provides another color in providing education for children with special needs. Education and teaching need to be pursued for a child's cognitive abilities to function positively and responsibly, especially for children with special needs who are learning to develop their 
potential. These efforts will positively impact the learning process, such as learning to read that must be mutilated by a child with special needs.

According to Bond (1975) in Mulyono (2003), it is revealed that reading is an early introduction of written language symbols in the form of stimulus to be read, to create an understanding through daily activities or experiences that have been done. Readers' ability to read starters is not only for children in general but also for children with special needs and need to master skills in reading starters such as children with multiple impairments. According to Sunanto (2013), children who experience various impairments simultaneously have specific learning needs given specifically and are caused by several combinations of barriers between physical, sensory, social, emotional, intellectual, and others.

The observations conducted in school show a problem that a child is categorized as a child with multiple impairments with two obstacles, namely impairment in physical and motor and intellectual impairment. Intellectual barriers experienced by children can hinder the learning process of one of them, namely the learning of reading the beginning. There are some problems in the child in the initial reading skills process. In reading, the child can get to know the alphabet just has not mastered everything. The child has not been able to spell letters but spell his name the child has been able to master. The child has also not mastered the merging of notes into a syllable or word. Efforts were made to achieve success in helping children improve their early reading learning skills by using Disability interactive media, which is expected to facilitate early reading learning.

Fauziah (2016) research shows that the use of interactive multimedia reading learning affects the improving early reading ability and a positive influence on the improvement of children's ability to read early in baseline phase 2 (A2) by $71.25 \%$ compared to baseline phase 1 (A1) by $10 \%$ in children with mild intellectual impairment. Other research was obtained by Fauzia and Kustiawan (2018) with the title "Interactive Multimedia to Improve Reading Ability of Students with Retardation." Stating that this research aims to produce interactive multimedia products. The interactive multimedia packaged in this CD is expected to increase the interest and ability of mentally disabled students to read early on. The results showed that interactive multimedia improved reading skills and were effective for mentally disabled students by obtaining a validation score of $97 \%$ of media experts. The effectiveness of interactive multimedia is proven effective, seen from the results tested with the T-Test receiving conclusions $t$ count five greater than t table 2,353, meaning the developed media is effectively applied in early reading learning for students with intellectual impairment. From the previous research, it can be concluded that interactive multimedia can improve reading skills in children with special needs. What distinguishes this research from previous research is that the subjects in this study are children with multiple barriers who have more than one 
developmental barrier, which causes difficulty in helping children with special needs to be increasingly difficult.

Thus, the study focused on two behavior targets that have been set, namely syllable reading ability and word reading ability. To achieve this target, researchers will use Disability interactive media to intervene to ease learning to read starters in children with multiple impairments grade III SDLB.

\section{Research Methodology}

The research method used by researchers is the quantitative research method. This type of research is a method of experimental research. According to Sugiyono (2016), practical research methods can be interpreted as research methods used to look for the influence of specific treatments on others under controlled conditions. The experimental research design used in this study is a single subject design or SingleSubject Research (SSR), a single subject design part of the practical research design that focuses on individual data as a research sample. Sunanto, Takeuchi, and Nakata (2006) reinforced this opinion, which states that the design of a single subject is the design of experimental research conducted on a relatively small number of issues. In this study, researchers used a single subject design to observe the initial condition before being given an intervention, when given intervention, and after being given an intervention. It aims to know the functional relationship between Disability Interactive Media and improved initial reading ability in children with multiple impairments.

The design used in this study uses a single subject design that is an A-B-A design. According to Sunanto, Takeuchi, and Nakata (2006), A-B-A's design indicates a causal relationship between bound variables and free variables. At first, target behavior is measured continuously at baseline condition (A1) for a certain period, then estimated at intervention condition (B), after which it is measured at baseline condition (A2). Baseline conditions (A2) are intended as controls for the intervention phase, making it possible to conclude the functional relationship between free and bound variables. Thus, the variable tied in this study is the ability to read starters in children with compound barriers. At the same time, the free variable in this study is Disability Interactive Media.

Due to the covid-19 pandemic, the government encouraged learning in schools to be moved home. So, this research was conducted in a house located in Sriwinangun, Rt/Rw. 053/024, Panjalu, Ciamis. In a face-to-face study, the investigation will also be completed online via video calls on the Whatsapp app and assisted by parents.

The subject of the study was a child with compound barriers who sat in grade III SDLB at SLB Agrowisata Shaleha Panjalu. Children who have multiple impairments have two blindness, namely tunadaksa accompanied by tunagrahita. This child is ten years old, has a complete physique, has difficulty walking, has no obstacles in both hands, and has below-average intellectuals. The child has a lively character, spoils his parents, and enjoys joking with his friends. Due to intellectual barriers, there are difficulties in the 
ability to read the beginning. As the child has not been able to know all the alphabet letters, has not been able to spell letters one by one, but the child has been able to spell the letters of his name, has not been able to compose syllables or words, and the child is still confused when reading the word. This child also sometimes feels saturation in learning, so the spirit of understanding until noon always wants to finish quickly. Therefore, children need to handle interventions to read early by using Disability interactive media to read. This research is perceived to help children learn to read.

Data collection techniques are the most strategic step in research because the primary purpose is to obtain data. Unfortunately, researchers will not get data that meets the data standards set (Sugiyono 2016). The data collection technique used in this study is to use research instruments carried out using observation, tests, and documentation. According to Arikunto (2006), observation is a narrow activity, i.e., paying attention to something using the eyes. The observations made in this study are structured observations that have been systematically designed about the research that will be observed, namely the influence of interactive media use of DISABILITY reading in improving abilities in children with compound barriers grade III SDLB. The test used in this study was an oral test to measure a child's early reading ability after being given intervention using Disability reading interactive media. The documentation used in this study is intended as a means of observation. Documentation is also used to take pictures in real time when the child is doing the initial reading learning process. So with the documents, there is authentic evidence of research done. In conducting observations researchers use research instruments that have tested their validity and reliability.

According to Sanjaya (2016), data analysis is a process of processing and interpreting data to collect various information according to its function to have a precise meaning following the research objectives. According to Abadi (2013), data analysis was carried out before entering the field, during the area, and after being in the field. In this study, several instruments were used to determine the improvement in initial reading ability using disability Interactive Reading media. Calculations in the analysis of observation sheet instrument data produce a percentage of further interpreted achievements with sentences. After obtaining the data and has calculated it into a percentage value, the data is presented with a graph. In this study, the data analysis used is a visual data analysis consisting of analysis in conditions such as the length of conditions, estimated directional tendencies, stability level, data footprint, stability and range level, level of change, and analysis of data between states including the number of variables changed, the trend of direction and effect, changes in stability tendencies, changes in levels, and overlap percentages.

\section{Results}

\subsection{Target BehaviorI (Ability to Read Syllables)}

Data obtained from the results of research on the ability to read syllables using interactive media disability to read in children with multiple obstacles, by collecting 
data for 16 sessions in 3 weeks consisting of 4 baseline sessions - 1 (A1), eight intervention sessions (B) and four baseline-2 sessions (A2) are described in the table below as follows:

Table 4.1 Measurement Results of the Ability to Read Syllables

\begin{tabular}{|c|c|}
\hline \multicolumn{2}{|c|}{ Baseline Phase- 1 (A1) } \\
\hline Session & Score \\
\hline 1 & $50 \%$ \\
\hline 2 & $50 \%$ \\
\hline 3 & $50 \%$ \\
\hline 4 & $50 \%$ \\
\hline \multicolumn{2}{|c|}{ Intervention Phase (B) } \\
\hline Session & Score \\
\hline 1 & $65 \%$ \\
\hline 2 & $81 \%$ \\
\hline 3 & $87 \%$ \\
\hline 4 & $85 \%$ \\
\hline 5 & $89 \%$ \\
\hline 6 & $94 \%$ \\
\hline 7 & $96 \%$ \\
\hline 8 & $98 \%$ \\
\hline \multicolumn{2}{|c|}{ Baseline Phase- 2 (A2) } \\
\hline Session & Score \\
\hline 1 & $75 \%$ \\
\hline 2 & $77 \%$ \\
\hline 3 & $79 \%$ \\
\hline 4 & $83 \%$ \\
\hline
\end{tabular}

Based on the results of measurements Table 4.1 the target behavior I, is the ability to read syllable is by using med he Disability interactive reading, can be seen in graph 4.1 as follows: 
Graph 4.1 Ability to Read Syllables in Baseline Phase - 1 (A1), Intervention Phase (B), and Baseline Phase - 2 (A2)

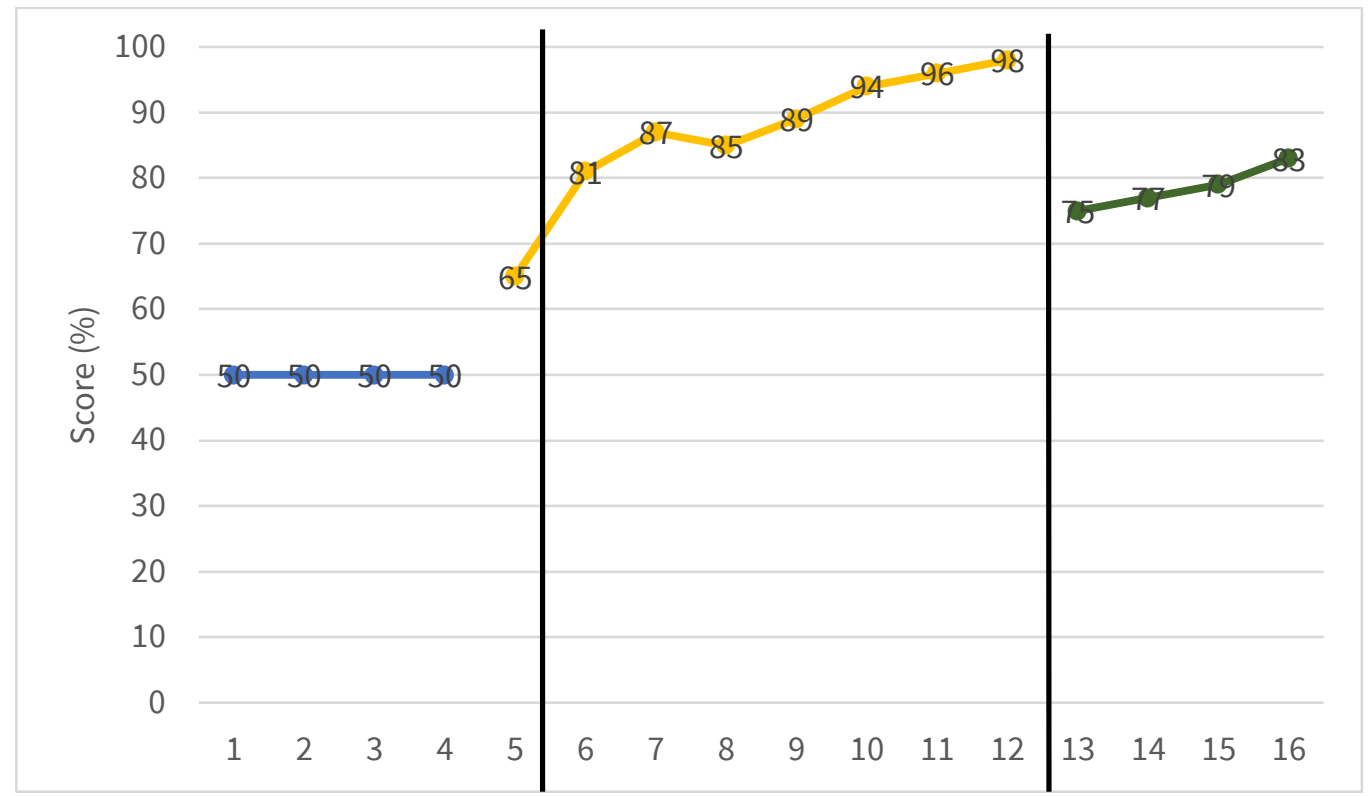

Graph 4.1 explains the data on the acquisition of the results of the research on the ability to read syllables in the baseline phase - 1 (A1), the intervention phase (B), and the baseline phase - 2 (A 2). The blue line in the chart explains the acquisition of data phase baseline - $1(\mathrm{~A} 1)$, the yellow line in the chart describes the data acquisition phase of the intervention $(B)$, and the green line represents the data acquisition phase of the baseline - 2 (A2).

The results of the analysis in terms of the ability to read syllables can be seen in Table 4.2 below:

Table 4.2 Summary of Analysis Results in Conditions on the Behavior Target of the Ability to Read Syllables

\begin{tabular}{|c|l|l|l|l|}
\hline No. & Condition & Baseline-1 (A1) & Intervention (B) & Baseline-2 (A2) \\
\hline 1. & Long condition & 4 & 8 & 4 \\
\hline 2. & $\begin{array}{l}\text { Estimated trend } \\
\text { direction }\end{array}$ & Stable & To increase & Toinerease \\
\hline 3. & $\begin{array}{l}\text { The trend of } \\
\text { data stability }\end{array}$ & $\begin{array}{l}4: 4 \\
\text { Stable }\end{array}$ & $\begin{array}{l}5: 8 \\
\text { Variable }\end{array}$ & $\begin{array}{l}4: 4 \\
\text { Stable }\end{array}$ \\
\hline 4. & Data trail & \multicolumn{1}{|c|}{$(=)$} & $(+)$ & \multicolumn{1}{c|}{$(+)$} \\
\hline 5. & $\begin{array}{l}\text { Level and range } \\
\text { stability }\end{array}$ & $\begin{array}{l}(50-50) \\
\text { Stable }\end{array}$ & $\begin{array}{l}(65-98) \\
\text { Variable }\end{array}$ & $\begin{array}{l}(75-83) \\
\text { Stable }\end{array}$ \\
\hline 6. & Level change & $\begin{array}{l}0 \\
(50-50) \\
(=)\end{array}$ & $\begin{array}{l}33 \\
(98-65) \\
(+)\end{array}$ & $\begin{array}{l}8 \\
(83-75) \\
(+)\end{array}$ \\
\hline
\end{tabular}


Based on table 4.2 above explains the summary of the results of the analysis in conditions on the target behavior of the ability to read syllables in the baseline phase - 1 (A1), the intervention phase (B), and the baseline phase - 2 (A 2). In addition, the length of the conditions carried out during the observation, namely in the baseline phase - 1 (A1) there were four sessions, in the intervention phase $(B)$ there were eight sessions, and in the baseline phase - 2 (A2) 4 sessions were carried out.

Estimated directional tendencies explain the change in each data from session to session. The baseline phase-1 (A1) trend line is stable because the percentage value obtained is the same from the first session to the fourth session. In the intervention phase (B), the trend line increases as the percentage value received increases from the first session to the last session. Finally, in the baseline phase- 2 (A2), the trend line of direction increases because the percentage value obtained increases from the first session to the last session.

Based on the calculation of stability tendency in baseline phase-1 (A1) is $100 \%$ (stable), intervention phase B is $62.5 \%$ (variable) and baseline phase-2 (A2) is $100 \%$ (stable).

A data-trace is a change in data from one data to another under a condition. For example, the baseline phase-1 (A1) data-trace tends to be flat because baseline phase-1 (A1) is an early condition of a child's ability to read syllables and has not been given intervention. Meanwhile, in the intervention phase (B), the data footprint tends to increase. Finally, in the baseline phase- 2 (A2), its data footprint tends to increase due to effective interventions.

The level and stability of the range in the baseline phase-1 (A1) is stable with a range of 0 , the intervention phase data $(B)$ increases variable by the field (33), and the baseline phase-2 (A2) increases steadily with the range (8).

The level change in baseline phase-1 (A1) indicates a sign (0) which means stable, in the intervention phase $(B)$ indicates a sign $(+33)$ that means an increase, and the baseline phase-2 (A2) indicates a sign (+8) that means an increase.

The results of analysis between conditions of syllable reading ability can be seen in Table 4.3 below: 
Table 4.3 Summary of Results of Inter-Condition Analysis on Target Behavior of Syllable Reading Ability

\begin{tabular}{|l|l|l|l|}
\hline No. & Conditions being compared & $\mathrm{B} / \mathrm{A} 1$ & $\mathrm{~A} 2 / \mathrm{B}$ \\
\hline 1. & Number of variables & 1 & 1 \\
\hline 2. & Change in direction and effects & $-\quad(+)(=)$ & $(+)(+)$ \\
\hline 3. & Change instability & $\begin{array}{l}\text { Variable to } \\
\text { stable }\end{array}$ & $\begin{array}{l}\text { Stable to } \\
\text { Variable }\end{array}$ \\
\hline 4. & Data level changes & $\begin{array}{l}(98-50) \\
+48\end{array}$ & $\begin{array}{l}(83-65) \\
+18\end{array}$ \\
\hline 5. & Overlapping percentage & 0 & 0 \\
\hline
\end{tabular}

Based on table 4.3 on the summary of the results of analysis between conditions on target behavior able reading ability with needs compared between baseline and intervention phases can be explained. The number of variables that will be changed in this study is seen in the target behavior target, which is the first target behavior regarding syllable reading ability. So, the number of variables in the analysis between these conditions amounts to 1.

The change in direction and effect can be seen from an inter-condition analysis of the first target behavior regarding the ability to read syllables in the intervention phase $(B)$ to the baseline phase- $1(A 1)$, indicating an increased direction to the flat. This is because the intervention phase (B) can affect the child in the initial condition of the child's ability or baseline phase-1 (A1), which indicates a tendency towards flat, and the intervention phase $(B)$ indicates an increased directional trend. The baseline phase- 2 (A2) to the intervention phase (B) shows an increased direction. This suggests that the intervention given to the child is very influential and has a good impact on the child's ability to read syllables.

Changes instability can be seen from its stability tendencies. The intervention phase (B) to baseline phase- 1 (A1) indicates the variable direction is stable. The baseline phase- 2 (A2) to the intervention phase (B) shows a steady approach to the variable.

In this study, the data level change in the intervention phase (B) to baseline phase- 1 (A1) got a calculation result of +48 , thus showing that the ability to read syllables in children with compound barriers increased significantly. While the change in the data level in the baseline phase- 2 (A2) to the intervention phase (B) gets a calculation result of +18 , this indicates an increase in data changes.

In this study, data overlap in the intervention phase (B) to baseline grade- 1 (A1) obtained results of 0 as well as in the baseline phase- 2 (A2) to the intervention phase (B), 
which received the same overlap data value. It can then be concluded that the intervention using Disability Interactive Media in children with compound barriers (tunadaksa and tunagrahita) shows a significant influence on the first target behavior, namely the ability to read syllables.

The comparison of the mean level or average value of the first target behavior, i.e., the ability to read syllables between baseline phase data- $1(A 1)$, intervention phase (B), and baseline phase- 2 (A2), can be described in graph 4.2 below, as follows:

Graph 4.2 Comparison of Mean Level Target Behavior I (Syllable Reading Ability) in Baseline Phase-1 (A1), Intervention Phase (B), and Baseline Phase-2 (A2)

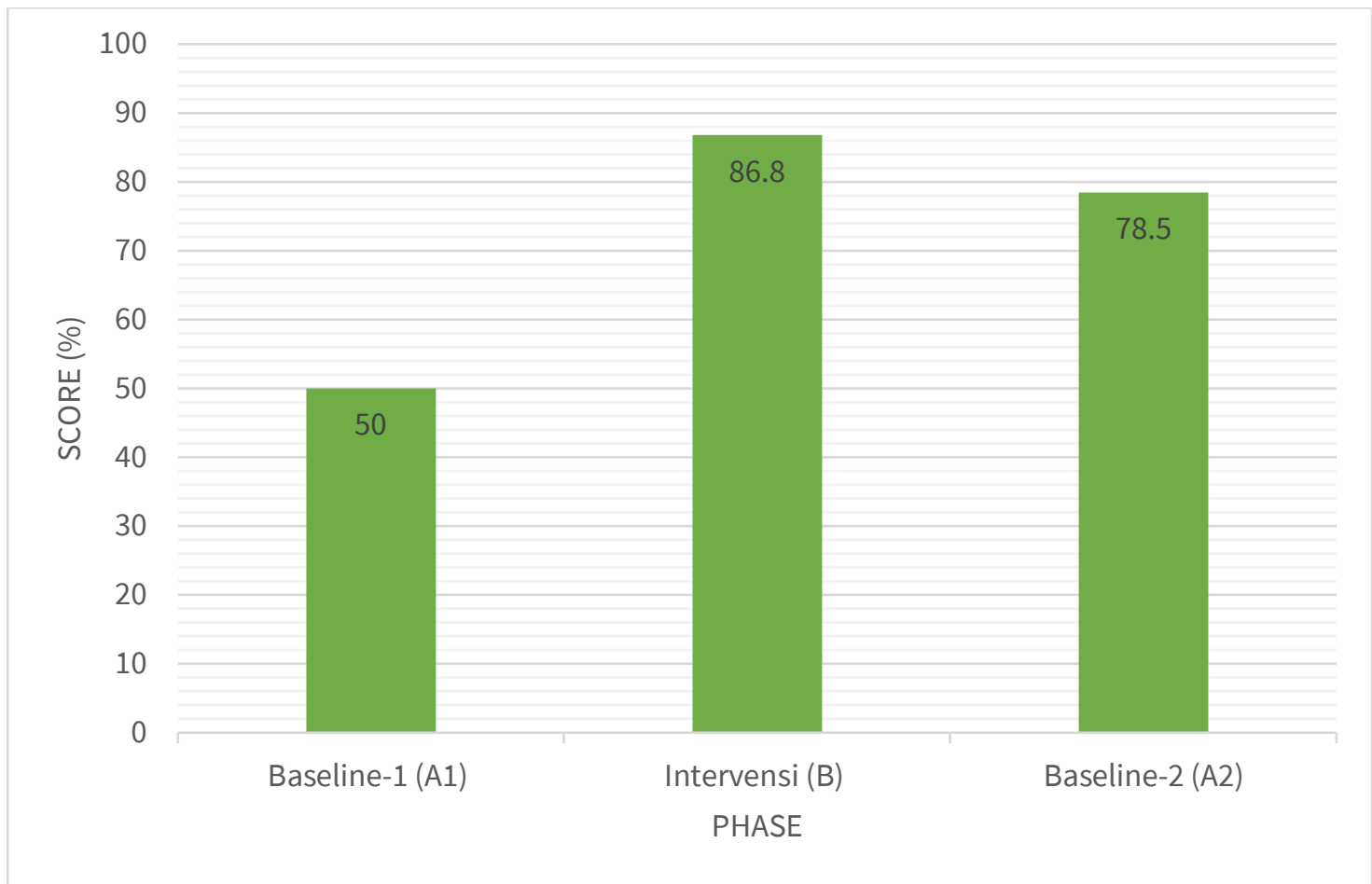

Based on graph 4.2 above on the comparison of mean levels in the first target behavior, namely the ability to read syllables in baseline phase- 1 (A1), intervention phase (B), and baseline phase-2 (A2). In the baseline phase- 1 (A1), the average value is 50 . In the intervention phase $(B)$, the average value is greater than the average value in the baseline phase- 1 (A1), 86.8. In the baseline phase- $2(A 2)$, the average value is below the intermediate intervention phase (B), 78.5.

\subsection{Target Behavior II (Word Reading Ability)}

Data obtained from the results of word reading skills study using Disability Interactive Media in children with compound barriers, with data collection for 16 sessions in 3 weeks consisting of 4 baseline sessions- 1 (A1), eight intervention sessions (B), and four baseline sessions- 2 (A2) described in table 4.4 below as follows: 
Table 4.4 Word Reading Measurement Results

\begin{tabular}{|c|c|}
\hline \multicolumn{2}{|c|}{ Baseline Phase- 1 (A1) } \\
\hline Session & Score \\
\hline 1 & $33 \%$ \\
\hline 2 & $33 \%$ \\
\hline 3 & $33 \%$ \\
\hline 4 & $33 \%$ \\
\hline \multicolumn{2}{|c|}{ Intervention Phase (B) } \\
\hline Session & Score \\
\hline 1 & $63 \%$ \\
\hline 2 & $71 \%$ \\
\hline 3 & $79 \%$ \\
\hline 4 & $79 \%$ \\
\hline 5 & $83 \%$ \\
\hline 6 & $88 \%$ \\
\hline 7 & $92 \%$ \\
\hline 8 & $96 \%$ \\
\hline \multicolumn{2}{|c|}{ Baseline Phase- 2 (A2) } \\
\hline Session & Score \\
\hline 1 & $67 \%$ \\
\hline 2 & $75 \%$ \\
\hline 3 & $83 \%$ \\
\hline 4 & $83 \%$ \\
\hline
\end{tabular}

Based on Table 4.4, results of measurement of target behavior II, namely the ability to read words by using Disability Interactive Media, can be seen in graph 4.3 as follows: 
Graph 4.3 Word Reading Ability in Baseline Phase- 1 (A1), Intervention Phase (B), and Baseline Phase-2 (A2)

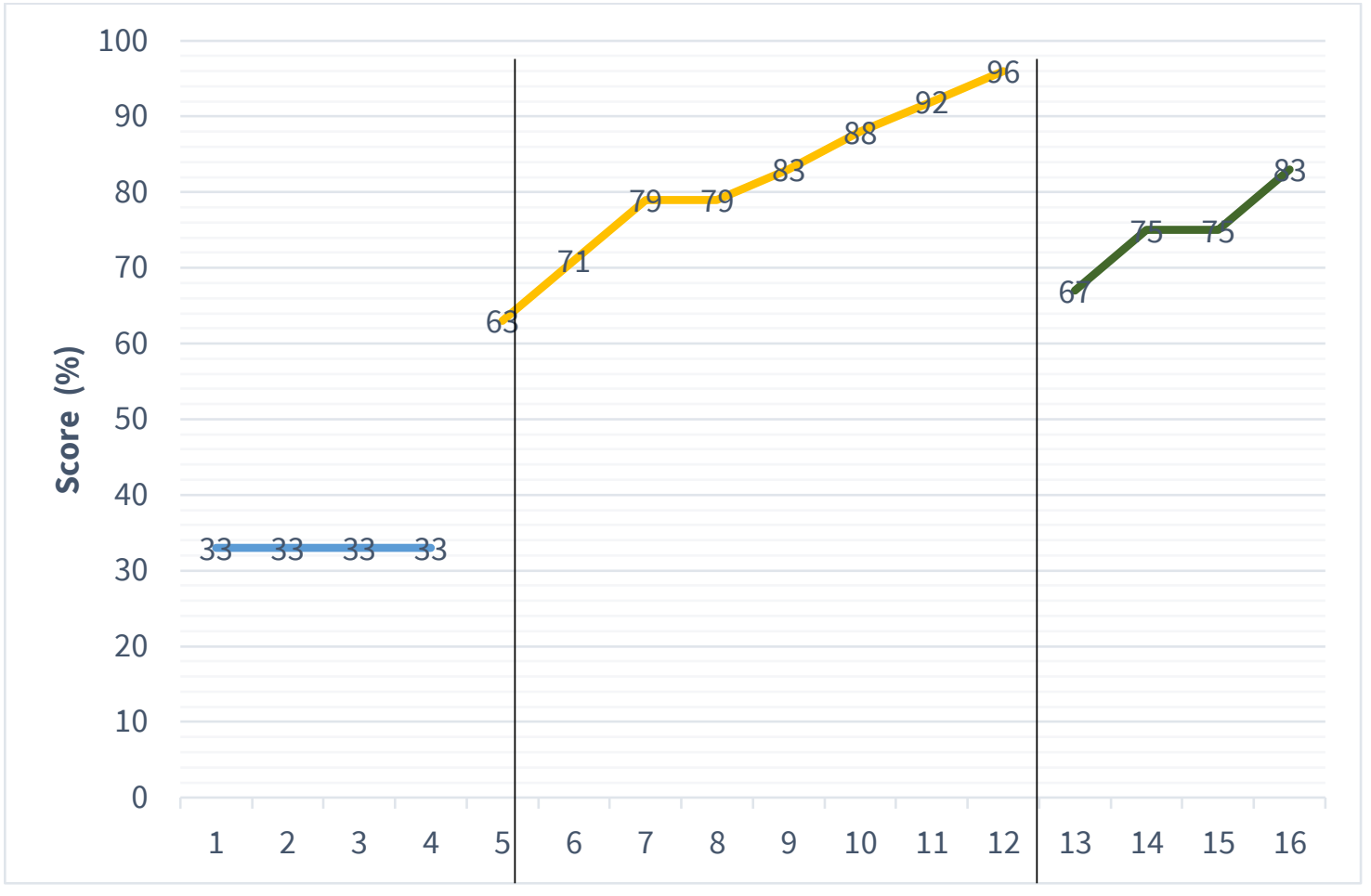

Graph 4.3 describes the data on the results of the word reading capability in the baseline phase- $1(A 1)$, intervention phase (B), and baseline phase-2 (A2). The blue line in the graph describes the acquisition of baseline-1 (A1) phase data, the yellow line in the chart represents the acquisition of intervention phase data $(B)$, and the green line describes the acquisition of baseline-2 (A2) phase data.

The results of the analysis in the condition of word reading ability can be seen in Table 4.5 below:

Table 4.5 Summary of Analysis Results in Conditions on Target Behavior of Word Reading Ability

\begin{tabular}{|c|c|c|c|c|}
\hline No. & Condition & Baseline - 1 (A1) & Intervention (B) & Baseline - 2 (A2) \\
\hline 1. & Long condition & 4 & 8 & 4 \\
\hline 2. & $\begin{array}{l}\text { Estimated trend } \\
\text { direction }\end{array}$ & $\overline{\text { Stable }}$ & To increase & $\widetilde{\text { To increase }}$ \\
\hline 3. & $\begin{array}{l}\text { The trend of data } \\
\text { stability }\end{array}$ & $\begin{array}{l}4: 4 \\
\text { Stable }\end{array}$ & $\begin{array}{l}\text { 4: } 8 \\
\text { Variable }\end{array}$ & $\begin{array}{l}4: 4 \\
\text { Stable }\end{array}$ \\
\hline 4. & Data trail & $(=)$ & $(+)$ & $\widehat{(+)}$ \\
\hline 5. & $\begin{array}{l}\text { Level and range } \\
\text { stability }\end{array}$ & $\begin{array}{l}(33-33) \\
\text { Stable }\end{array}$ & $\begin{array}{l}(63-96) \\
\text { Variable }\end{array}$ & $\begin{array}{l}(67-83) \\
\text { Stable }\end{array}$ \\
\hline 6. & Level change & $\begin{array}{l}0 \\
(33-33) \\
(=)\end{array}$ & $\begin{array}{l}33 \\
(96-63) \\
(+)\end{array}$ & $\begin{array}{l}16 \\
(83-67) \\
(+)\end{array}$ \\
\hline
\end{tabular}


Based on table 4.5 above, summarize the analysis results in conditions on target behavior of word reading ability in baseline phase-1 (A1), intervention phase (B), and baseline phase-2 (A2). The length of conditions performed during observation is that in the baseline phase- 1 (A1) is carried out four sessions, in the intervention phase (B) is carried out eight sessions, and in the baseline phase- 2 (A2) is carried out four sessions.

Estimated directional tendencies explain the change in each data from session to session. The baseline phase-1 (A1) trend line is stable because the percentage value obtained is the same from the first session to the fourth session. In the intervention phase $(B)$, the trend line increases as the percentage value received increases from the first session to the last session. Finally, in the baseline phase- 2 (A2), the trend line of direction increases because the percentage value obtained increases from the first session to the last session.

Based on the calculation of stability tendencies in baseline phase-1 (A1) is $100 \%$ (stable), intervention phase B is $50 \%$ (variable) and baseline phase-2 (A2) is $100 \%$ (stable).

A data-trace is a change in data from one data to another under a condition. For example, the baseline phase-1 (A1) data-trace tends to be flat because baseline phase-1 (A1) is an early condition of a child's ability to read syllables and has not been given intervention. Meanwhile, in the intervention phase (B), the data footprint tends to increase. Finally, in the baseline phase- 2 (A2), its data footprint tends to increase due to effective interventions.

The level and stability of the range in the baseline phase-1 (A1) is stable with a range of 0 , the intervention phase data $(B)$ increases variable by the field (33), and the baseline phase-2 (A2) increases steadily with the range (16).

The level change in the baseline phase-1 (A1) indicates a sign (0) which means stable, in the intervention phase $(B)$ indicates a sign (+33) that means an increase, and the baseline phase-2 (A2) indicates a sign $(+16)$ that means an increase.

The results of analysis between conditions of syllable reading ability can be seen in Table 4.6 below: 
Table 4.6 Summary of Results of Inter-Condition Analysis on Target Behavior of Word Reading Ability

\begin{tabular}{|l|l|l|l|}
\hline No. & Conditions being compared & B / A1 & A2 / B \\
\hline 1. & Number of variables & \multicolumn{1}{|c|}{1} & \multicolumn{1}{|c|}{1} \\
\hline 2. & Change in direction and effects & $\begin{array}{l}(+)(=) \\
(+)(+)\end{array}$ \\
\hline 3. & Change instability & Variable to stable & Stable to variable \\
\hline 4. & Data level changes & $\begin{array}{l}(96-33) \\
+63\end{array}$ & $\begin{array}{l}(83-63) \\
+20\end{array}$ \\
\hline 5. & Overlapping percentage & 0 & $25 \%$ \\
\hline
\end{tabular}

Based on table 4.6 on the summary of the analysis results between conditions on target behavior, word reading with needs compared between baseline and intervention phases can be explained. The number of variables that will be changed in this study is seen in the target behavior target, the second target behavior regarding word reading ability. So, the number of variables in the analysis between these conditions amounts to 1.

The change in direction and effect can be seen from the analysis results between conditions towards the second behavior target regarding reading words in the intervention phase $(B)$ to the baseline phase- $1(A 1)$, indicating an increased direction flat. This is because the intervention phase $(B)$ can affect the child in the initial condition of the child's ability or baseline phase-1 (A1), which indicates a tendency towards flat, and the intervention phase $(B)$ indicates an increased directional trend. The baseline phase- 2 (A2) to the intervention phase (B) shows an increased direction.

Change's instability can be seen from its stability tendencies. Then the intervention phase $(B)$ to baseline phase-1 $(A 1)$ indicates the variable directly to stable. While in the baseline phase- 2 (A2) to the intervention phase (B) shows a stable direction to the variable.

In this study, the data level change in the intervention phase $(B)$ to baseline phase- 1 (A1) got a calculation result of +63 , thus showing that the ability to read words in children with compound barriers increased significantly. While the change in data level in baseline phase- 2 (A2) to intervention phase (B) gets a calculation result of +20 , this indicates an increase in data changes.

In this study, the data overlap in the intervention phase (B) to the baseline phase1 (A1) got results of $0 \%$ and in the baseline phase- 2 (A2) to the intervention phase (B) got an overlap data value of $25 \%$. It can then be concluded that the intervention using Disability interactive media of reading in children with compound barriers shows a significant influence on the second behavior target, namely the ability to read words. 
The comparison of the mean level or average value of the second target behavior, i.e., the ability to read words between baseline phase data- 1 (A1), intervention phase (B), and baseline phase- 2 (A2), can be described in graph 4.4 below, as follows:

Graph 4.4 Comparison of Mean Level Target Behavior II (Word Reading Ability) in Baseline

Phase-1 (A1), Intervention Phase (B), and Baseline Phase-2 (A2)

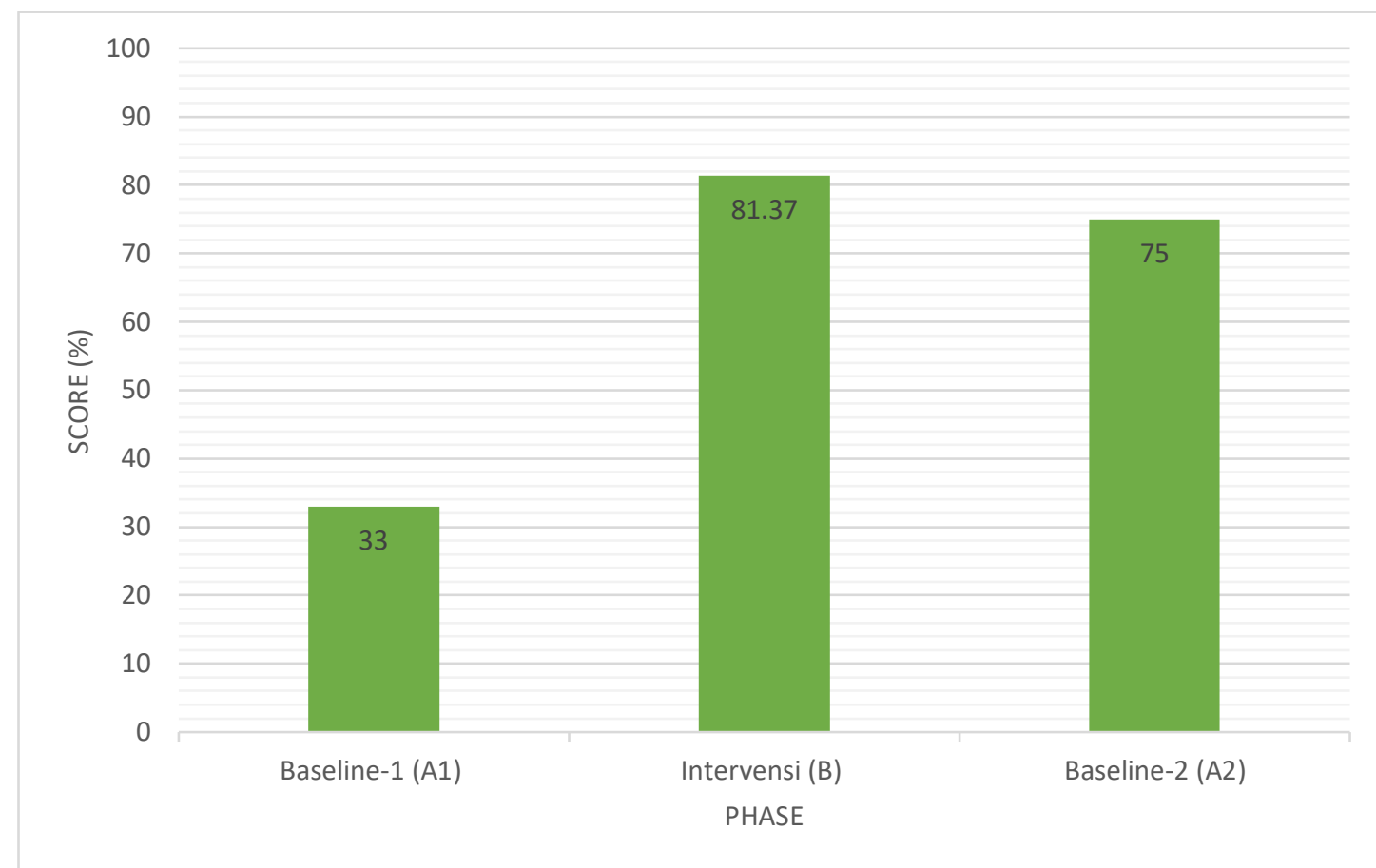

Based on graph 4.4 above on the comparison of mean levels in the first target behavior, namely the ability to read words in the baseline phase- 1 (A1), intervention phase (B), and baseline phase- $2(A 2)$. In the baseline phase- $1(A 1)$, the average value is $33 \%$. In the intervention phase $(B)$, the average value is greater than the average value in the baseline phase- $1(\mathrm{~A} 1), 81.37 \%$. Finally, in the baseline phase- $2(\mathrm{~A} 2)$, the average value is below the intermediate intervention phase (B), $75 \%$.

\section{Research Discussion}

Before the study was conducted, researchers made observations first in children with compound barriers (tunadaksa accompanied by tunagrahita). There are some problems faced by children, namely difficulty in reading the beginning. Some of the reading learning process problems, namely in mentioning the letters of the alphabet and spelling letters, the child is also unable to combine letters into one syllable or word.

If the child's problems are not changed, it will impact the child's learning outcomes.

Based on the problems that have been presented, problem solving or solutions in this study is to provide intervention or treatment to the child by using Disability Interactive Media that can improve the initial reading ability. The interactive media 
Disability reading is a medium with elements of images, sounds, and animations, making it easier for children to understand reading and memorizing letters and words. This media successfully attracts children to learn to read by being given fun activities in learning to read. This media also has exciting games that can be used as evaluation material in the research process and not burden the child in carrying out tests.

Based on the research results that have been conducted for three weeks, intervention activities that have been carried out have a tremendous influence and can improve the ability to read starters in children. The initial reading ability in this study has target behavior targets, namely the ability to read syllables and read words. As for the mean level comparison value in the first target behavior, namely the ability to read

syllables between baseline phases- 1 (A1) get an average value of $50 \%$, the intervention phase (B) receives an average value of $86.8 \%$, and the baseline phase- 2 (A2) earns an average score of $78.5 \%$. Then, the mean level comparison value in the second target behavior, namely the ability to read words between baseline phases- 1 (A1) gets an average value of $33 \%$, the intervention phase (B) receives an average value of $81.37 \%$, and the baseline phase- 2 (A2) earns an average score of $75 \%$.

With Disability Interactive Media, the process of intervention activities in providing syllable and word reading lesson materials can be done in a way that is fun and interests the child to learn. With this medium, children can understand the learning materials and the ability of children to be improved. Mintorogo, Adib, and Suhartono (2014) revealed that "interactive media makes children happy to learn and beneficial for the development of children's personalities, namely in cognitive abilities as well as in interacting with others. The development of game elements in interactive media can develop the left brain and right brain by providing stimulus and developing creativity in children". The influence of both interactive disability media use of reading can indicate success in children, and children can already read a few words even though the child is still spelling a little. According to Basori (2016) who revealed that "interactive media provides great benefits in the learning process such as improving understanding and improving children's learning achievement." Thus intervention activities using Disability Interactive Media in children with compound barriers grade III SDLB effectively teach to read syllables and read words.

\section{Conclusion}

Based on the results of the study, it can be concluded that Disability Interactive Media can improve the pre-reading ability of children with multiple disabilities with the target behavior of the ability to read syllables and the ability to read words. The results of this study can be shown by a comparison of the mean level values in each phase. For example, in the target behavior of syllable reading ability, baseline phase-1 (A1) gets a stable value, the intervention phase (B) receives an increased weight, and the baseline phase-2 (A2) gets a moderately increased value. Similarly, the mean level comparison in the second target behavior is the ability to read words. From these results, interactive 
media disability reading can improve the ability to read starters in children with compound barriers (tunadaksa accompanied by tunagrahita) grade III SDLB.

\section{References}

Abadi, Reza Febri. 2013. "Pengembangan Media Alternatif And Augmentatif Communication (AAC) Dalam Mengembangkan Keterampilan Komunikasi Pada Anak Dengan Hambatan Komunikasi."Bandung: UPI.

Arikunto, Suharsimi. 2006. "Prosedur Penelitian Suatu Tindakan Praktik." Jakarta: Rineka Cipta.

Basori, Muhamad. 2016. "Pengembangan Multimedia Interaktif Untuk Mata Pelajaran Ilmu Pengetahuan Sosial (IPS) Sekolah Dasar Kelas V." Jurnal Pendidikan Dasar Nusantara 1(2).

Fauzia, Atifah, and Usep Kustiawan. 2018. "Multimedia Interaktif Untuk Meningkatkan Kemampuan Membaca Permulaan Siswa Tunagrahita." Jurnal Ortopedagogia 3(1): 6-12.

Fauziah, Pupu. 2016. "PENGGUNAAN MULTIMEDIA INTERAKTIF CERDAS BELAJAR BACA DALAM MENINGKATKAN KEMAMPUAN MEMBACA PERMULAAN PADA ANAK TUNAGRAHITA RINGAN (Studi Eksperimen Dengan Desain Single Subject Research Terhadap Siswa Tunagrahita Ringan Kelas III SDLB C Cinta Asih)." UNIK (Jurnal Ilmiah Pendidikan Luar Biasa) 1(1).

Mintorogo, Jessica Michaela, Ahmad Adib, and Ani Wijayanti Suhartono. 2014. "Perancangan Media Interaktif Pengenalan Alphabet Berbasis Alat Permainan Edukatif Untuk Anak Usia 2-4 Tahun." Jurnal DKV Adiwarna.

Mulyono, Abdurrahman. 2003. "Pendidikan Bagi Anak Berkesulitan Belajar." Jakarta: Rineka CiptaMulyono, A. (2003). Pendidikan bagi anak berkesulitan belajar. Jakarta: Rineka Cipta, 33339. https://doi.org/10.1016/j.jcjo.2015.03.008.

Sanjaya, D R H Wina. 2016. Penelitian Tindakan Kelas. Prenada Media.

Sugiyono. 2016. "Metode Penelitian Kuantitatif Kualitataif Dan Kombinasi (Mixed Methods)." Journal of Chemical Information and Modeling.

Sunanto, Juang. 2013. 12 Jassi Anakku Konsep Dasar Individu Dengan Hambatan Majemuk.

Sunanto, Juang, Koji Takeuchi, and Hideo Nakata. 2006. Penelitian Dengan Subjek Tunggal. Bandung: UPI Pres. 